\title{
Exploration on Experimental Teaching Model of Financial Management Specialty under the Environment of Simulation
}

\author{
Jie Li \\ Xi'an FanYi University \\ Xi'an, China 710105
}

\begin{abstract}
With the pace of the information age and the requirements of application-oriented talents training, simulation technology has been widely applied to the experimental teaching process. This paper analyzes the problems underlying the traditional experimental teaching modes in terms of university financial management, and designs a new teaching mode for the financial management professional from four aspects of individual experiments, experimental skills, comprehensive experiments, and innovative experiments. Finally, with the considerations of investment intensity, teaching staff, teaching content, and teaching methods, this paper puts forward some suggestions to improve the hierarchical simulation teaching mode of financial management.
\end{abstract}

Keywords-simulation; financial management; the experimental teaching model

\section{INTRODUCTION}

Going with the rapid changes in social environment, the market demand for financial executives is gradually tending to those who are applied and innovative. Some of domestic scholars have started researches on financial management specialty experimental teaching, such as Huang Xinrong (2011) who raised improved ERP experimental teaching system; Yang Fan (2013) who conducted innovative and optimized researches on financial management specialty experimental teaching through course system, experimental contents and methods. Shao Qinghong et al (2015) who conducted deep researches on status quo and problems of financial management specialty experimental teaching in Tibet University; Zhang Gaosheng (2015) who applied simulation technique into experimental teaching to study the construction of financial management specialty experimental teaching in a simulation environment. The experimental teaching of financial management specialty is a teaching method which makes use of modern computer and network to simulate real scene, environment, flow, data and business in an enterprise to design teaching links so as to combine theories and practices through experiences [1], all of the researches are used as basis and references for this article.

Fund Program: Education and Teaching Reforms in Xi'an Fanyi University (J17B12); Xi' an Fanyi University, Economic Law, Self-Designed Textbook (JC14B04); Education Department of Shaanxi Province (17JK0986). Xi'an Fanyi University, Microeconomics Teaching Team(Z1208)
Nowadays, in order to cultivate talents meeting the market demand, colleges have launched a string of experimental teaching on financial management specialty and achieved a lot, however, there are still more needing reforms and exploration. Based on problems existing in financial management specialty experimental teaching in colleges, this article makes a deep discussion on the construction of financial management specialty experimental teaching in a simulation environment.

\section{Status QuO OF Financial Management SPECIALTy EXPERIMENTAL TEACHING IN COLLEGES}

\section{A. Poor Understanding and Investment in Financial Management Specialty Experimental Teaching}

Most of colleges are focused on the construction of theory teaching, teaching contents and textbooks, ignoring the construction of experimental teaching. Many colleges which have set financial management specialty only arrange students to try accounting operation at accounting labs, having no a complete in-campus financial management experimental platform. Besides, though many experimental courses are set in colleges, yet there are few class hours, and there are no adequate equipment and software, and some are only set in form, and there are eventually no efficient experiments for students to do. [2]

\section{B. Lack of Practical Abilities of Financial Management Teachers}

Currently applied talents are mostly demanded in society, and what the most to cultivate the applied talents is applied teachers. Teachers who teach experimental courses shall first have professional knowledge as well as rich practical abilities. Yet most of financial management teachers in colleges have no specific work experience but they begin teaching after graduation from colleges. In the meantime, most of top colleges are focused on teachers abilities in scientific research, which greatly encourage teachers for scientific research but pay little attentions to cultivating teachers' abilities in experiment and practice. [3] During the practical teaching, most teachers only teach according to theory teaching, having no design of practical applied environment. 


\section{Single Contents in Financial Management Experimental Teaching}

The surveys of practical teaching of financial management and accounting in our college show, the practical contents are limited to theoretical courses and non-systematic [4]; generally it targets single experiment and skill experience, having no comprehensive experiments at different levels and aspects. Second, there are single items for experiment, mostly aimed at accounting courses such as Computer-Aid Accounting, Fundamental Accounting, and most financial management courses based on class discussion and almost no experiment such as Fundamentals of Financial Management, Cost Accounting and Assets Estimation and so on.

\section{Outdated Methods and Means in Financial Management Experimental Teaching}

At present, the financial management experimental teaching in most colleges is mainly done in class, and only financial software are arranged for operation yet without computer-aid simulation experiment. Main teaching methods and means are demo teaching, generally teachers make demo through software, then students will learn how to use the software and operate on computers, students should be required to do independently. Through general financial software for experiment, it has advantages such as low costs, repeated experiment and designable cases and more, yet to some degree, the simulation seems fart to be real, having no individual characteristics of enterprises.

\section{DESIGN OF FINANCIAL MANAGEMENT EXPERIMENTAL TEACHING MODE UNDER A SIMULATION ENVIRONMENT}

As what shown above, traditional experimental teaching is unable to meet market demand for applied, compound and innovative talents in financial management. In order to cultivate market oriented talents, the talent cultivation of financial management shall be focused on professional capability, practical capability, comprehensive application skills and innovation and startup. Based on goals of financial management talents cultivation, this article raises the following methods: simulate financial management process, design from single to comprehensive, stress core capability cultivation and progressive graded simulation experimental teaching mode om "Fig 1", make students be based on professional knowledge, improve comprehensive quality in all aspects, improve professional adaptation and expansion capability, enabling students to master how to apply, analyze, integrate and estimate what they have learned [5].
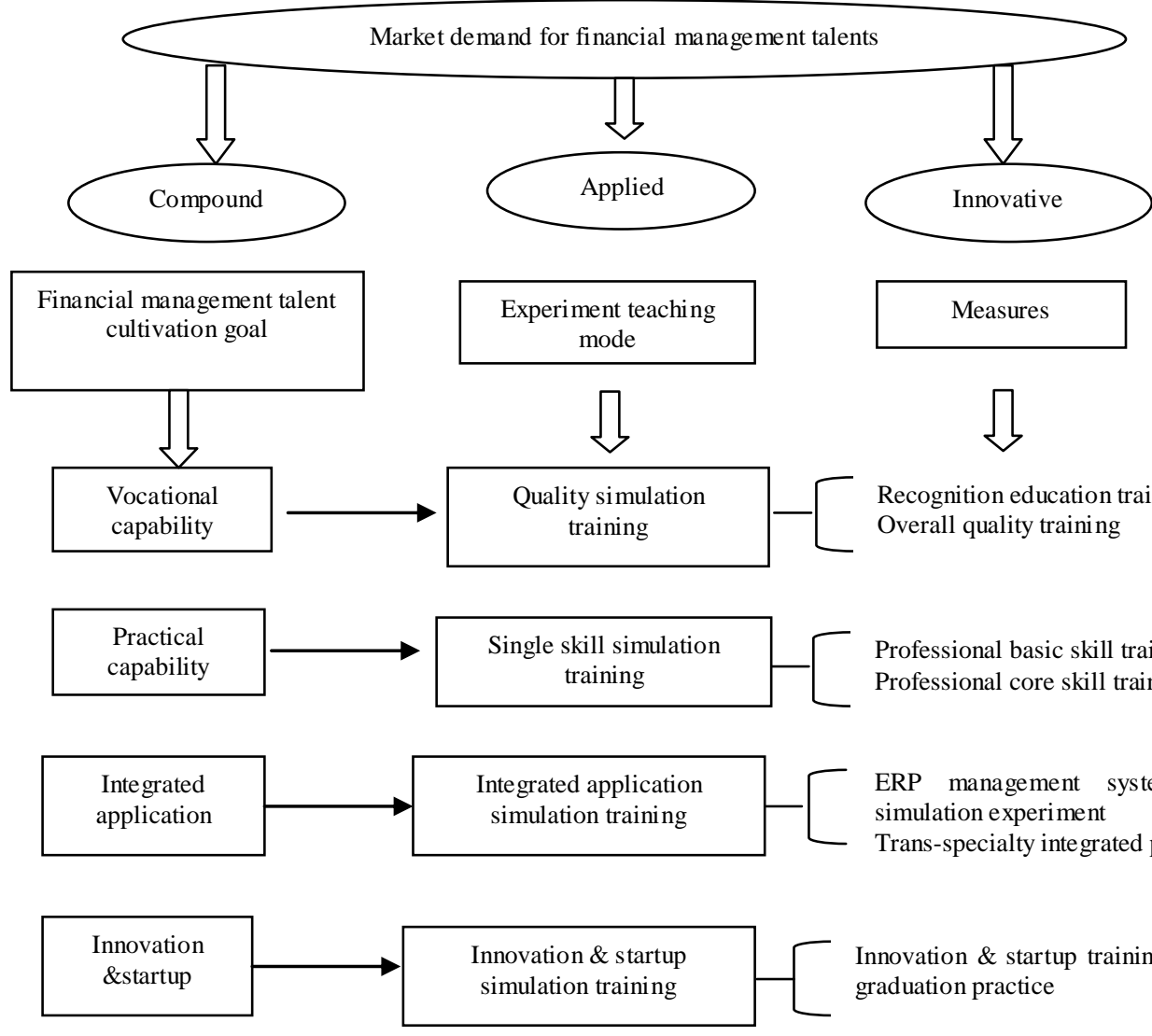

Recognition education training Overall quality training

Professional basic skill training Professional core skill training

ERP management system simulation and financial simulation experiment

Trans-specialty integrated practice teaching platform VBSE

Innovation \& startup training, subject competition, graduation practice

Fig. 1. Graded simulation experimental teaching mode aimed at professional talent cultivation. 


\section{A. Quality Simulation Training}

The module is mainly focused on students' basic professional attainment and quality training. First, training of cognition education, double-qualification teachers having rich experience will be invited for introducing professional knowledge before enrollment, analyzing work post, work task and flow related to financial management and licensing capability needed for completing financial management tasks. Students can have their all-sided quality trained through participation in social activities, social groups, and social practices in holidays and so on. It is focused on training students' capabilities in communication, organization, coordination, morality and etiquette. In the meantime, teachers are requested to introduce more enterprise practice cases in order to help students master theoretical knowledge specifically, or take students to visit in enterprises or bring static economic business on books to reality where students feel what the practices are and understand it really.

\section{B. Single Skill Simulation Training}

The module is focused on students' skill training in information process and financial software operation, through which, students can master basic financial theories, knowledge and methods in order to place a solid theoretical foundation for the next-level comprehensive experimental design. First, training of professional basic skills, through a string of trainings such as fundamentals of computer, management information system simulation experiment, SPSS software simulation experiment, Excel functions and so on; students will be trained in information process, computer operation and other professional skills. II. Core skill training aimed at all links of financial work, including hand-operated accounting simulation experiment, computer-aided accounting experiment, financial information system training, ERP sand table simulation experiment, financial business simulation and so on. During teaching, design experiment items separately according to functions and basic operation of computer-aided accounting software such as creating financial statements, setting subject administrative rights, drawing basic financial analysis figures and applying general function of financial management; Set experiment items as per key knowledge of financial courses, for example, exercise decision-making on financing through financial business simulation training and enterprises and individual financial simulation training, exercise capital operation and management through computer-aided financial management simulation experiment, and exercise profits management through enterprise simulation cases analysis.

\section{Comprehensively Applied Simulation Training}

The module is mainly focused on students' capabilities in comprehensive application of courses of diverse subjects and specialties as well as professional knowledge and skills to solve problems. Main teaching links and training methods include ERP management system simulation experiment, financial simulation lab, trans-specialty comprehensive practice teaching platform VBSE and so on. It is recommended to build a financial simulation lab professionally used for financial management students. For example, in the financial management lab, teachers can take the class as a listed company or enterprise, set shareholders' meeting, board of directors, management, financial department, production department and so on, applying multimedia technologies to show the real work scenes, enable students to act as decision makers in the experiment and experience the whole course from project selection, financing, investment and financial decision making, besides, more students can be arranged for operation in order to overcome the limit of individual operation on computers in traditional experiments. [6] And the students can also bring questionable decisions in learning to the experiment for confirmation.

\section{Innovative and Startup Simulation Training}

The module is mainly focused on students' capabilities in innovation and startup, aimed at verifying the teaching effect. Main teaching links and training methods include innovation and startup training, subject contests and graduation practice. The higher level of financial management teaching can be called students' startup experiment, relying on practices in real enterprises; students can apply what they have learned in class in real enterprise operation. For example, set up an enterprise and accounting consultancy center, which consists of teachers and students, most of whom are junior students, mainly responsible for agency account, financial consultancy, tax payment planning, assets evaluation and so on. The center may provide students with such a platform for exercising business and accumulating experience. According to characteristics of the specialty, organize professional skill contests such as management consultancy challenge match, financial analysis challenge match and more, which will help students form capabilities of independent learning and innovation. With regard to graduation practice, colleges shall strengthen the construction of out-of-campus experimental bases, establishing long term cooperation with enterprises and public institutions and signing agreements concerning undergraduate practice instruction.

\section{CONCLUSION}

\section{A. Value Experimental Teaching and Create a Perfect Simulation Experimental Teaching Platform}

First, colleges and teachers should completely change the concept "Value theories yet ignore practices", and improve the recognition of comprehensive and design experiments and practical teaching. Second, colleges should increase investments in experiment teaching and build a perfect simulation experiment teaching platform, making students to make experiments in a mighty real environment in order to improve students' interests in simulation and experimental effect. For example, the requirements on experimental teaching hardware and software in the graded simulation experiment teaching mode raised in this article can be used as references to perfect our experiment teaching platform; relying on industry-university and research combination, collegeenterprise cooperation and joint cultivation, colleges and enterprises can jointly build out-of-campus practice platforms. Create out-of-campus practice training platforms through students' societies and associations; create innovative practice platforms through scientific research projects, startup projects 
and innovative projects; create system safeguard platforms through improving practice teaching management and evaluation system.

\section{B. Cultivate Teachers' Abilities in Practice and Comprehensive Quality}

Colleges may launch diverse training to improve teachers' practical operation skills in order to improve teachers' abilities in experiment instruction. For example, encourage experiment course teachers to participate in financial management practice in some enterprise financial departments to fully understand financial problems in practice; experienced experts can be invited as well to train teachers, and class teaches can be sent to enterprises for post training regularly. With regard to graduates who are employed directly, arrange experienced technicians for instruction, help and support, enabling them to grasp experimental methods and how to operate experimental software. In the meantime, supervision groups shall strengthen experimental courses teaching examination and instruction so as to improve the teaching effect.

\section{Break through Single Experimental Teaching Contents and Create a Graded Experiment Teaching Mode}

Traditional financial experiments are focused on accounting simulation, and only individuals conduct experiments through computers, which cause failure to conduct real and all-sided simulation over real financial flow in enterprises. Graded teaching experiment teaching mode requires creating a financial simulation lab in a college, the comprehensive financial experiment stresses that students should conduct team experiments, emphasizing the mutual penetrations between professional knowledge and comprehensive practice exercises, improving students' practical competence and team work spirit. Relying on special financial simulation software, teachers can simulate the whole course of production and operation in an enterprise, many forms such as character playing, scenario simulation and teachers' estimation are adopted to make students engage in financial activities such as financing, investment and distribution in virtual market competition environment. Based on professional knowledge, students can have their comprehensive quality improved, really learning how to apply, analyze, integrate and evaluate what they have learned.

\section{Improve Teaching Methods and Means and Adopt Multiplex Experiment Teaching}

Currently financial experiments in some colleges are based on class and general financial software exercise, due to single environment and differences from practice, most students show no interests. Therefore, it is recommended that during the experiment teaching, many forms should be carried out such as in-campus experience, out-of-campus exercise and professional skill competition, during all of the experiments, manual operation should be combined as possibly as we can with computer, network and simulation experiments [7]. During the optimization of financial experience course in our college, diverse means are adopted as well; ERP software and online platform are used for enterprise operation simulation experiment and securities investment simulation experiment so as to improve the experiment reality as possibly as we can. Experiment results show, most students are interested in such as exercises and participating actively, getting sound effect.

\section{REFERENCES}

[1] Zhang Gaosheng, Exploring Financial Management Experiment Teaching Mode on the Basis of Simulation Environment [J]. Higher Education, 2015(15): 34.

[2] Wang Minghu, Optimization of Financial Management Experiment Teaching Links [J]. Journal of Anhui University of Technology(Social Sciences), 2009(3): 124.

[3] Xing Wenyan, Xu Shumin, Initial Discussion on Financial Management Experiment Teaching Reform in Colleges [J]. Financial News, 2009 (8): 50

[4] Yang Fan, Researches on Optimization of Applied Financial Management Experiment Teaching System [J]. Commercial Accounting, 2013(24): 126.

[5] Su Ling, Comprehensive and Design Experiment and Practical Teaching of Financial Management: Exploration and Practice [J]. China Township Enterprise Accounting, 2015(6): 46.

[6] Yuan Chunsheng, Contents Design and Quality Control of Financial Management Experiment Teaching [J]. Journal of Higher Economics Finance, 2011(9): 46

[7] Shao Qinghong, Hou Xia, Zhang Xiaoli et al, Discussion on Financial Management Experiment Teaching Reforms in Tibet Colleges [J]. China Township Enterprise Accounting, 2015(6): 160. 